\title{
Effect of the incorporation of sugarcane bagasse fibers in asphalt mixture dosed by
}

\section{the Superpave method}

\section{Efeito da incorporação de fibras do bagaço de cana em mistura asfáltica dosada pelo método}

\section{Superpave}

Efecto de la incorporación de fibras de cane bagasse en mezcla dosificación de asfalto por el método

\section{Superpave}

Ana Maria Gonçalves Duarte Mendonça ORCID: https://orcid.org/0000-0002-4595-2959 Federal University of Campina Grande, Brazil E-mail: prof.anamariaduarte@gmail.com

Osires de Medeiros Melo Neto ORCID: https://orcid.org/0000-0002-2535-0969 Federal University of Campina Grande, Brazil E-mail: osiresdemedeiros@gmail.com

John Kennedy Guedes Rodrigues ORCID: https://orcid.org/0000-0003-0340-5567

Federal University of Campina Grande, Brazil E-mail: profkennedy@hotmail.com

Robson Kel Batista de Lima ORCID: https://orcid.org/0000-0001-6917-9895 Federal University of Campina Grande, Brazil E-mail: robsonkel1@gmail.com

Ingridy Minervina Silva

ORCID: https://orcid.org/0000-0003-2538-9166

Federal University of Campina Grande, Brazil

E-mail: minervinaingridy@gmail.com

Valter Ferreira de Sousa Neto

ORCID: https://orcid.org/0000-0001-9759-7947

Federal University of Campina Grande, Brazil E-mail: valterneto51@gmail.com

Flávia do Socorro de Sousa Carvalho ORCID: https://orcid.org/0000-0003-0248-2990

Federal University of Campina Grande, Brazil E-mail: flaviasousa.ec@hotmail.com

Yane Coutinho

ORCID: https://orcid.org/0000-0001-8781-0388

Federal University of Pernambuco, Brazil E-mail: yane_coutinho@hotmail.com

Amanda Jessica Rodrigues da Silva

ORCID: https://orcid.org/0000-0001-7051-8786

Federal University of Campina Grande, Brazil

E-mail: amanda.jessica2seg@gmail.com

Thamires Dantas Guerra

ORCID: https://orcid.org/0000-0002-4259-7832

Federal University of Campina Grande, Brazil

E-mail: thamires_guerra@hotmail.com

\begin{abstract}
Sugar industry waste bagasse contains many natural fiber materials, and the application of natural fibers in asphalt mixes such as SMA (Stone Matrix Asphalt) has become an attractive alternative for the construction of flexible pavements. This study aims to evaluate the mechanical performance of an asphalt mixture modified by incorporating $0.3 \%$ sugarcane bagasse fiber and with a size of $20 \mathrm{~mm}$. The asphalt binder was submitted to penetration, softening point, and rotational viscosity tests to carry out this research, and the aggregates were characterized by specific mass, particle size, and absorption tests. Furthermore, the Superpave dosage was performed to produce the specimens to be evaluated in the splitting tensile strength test, resilient modulus, Marshall stability, and draindown sensitivity. As a result, the modified asphalt mixture presented a better performance in all evaluated strength tests and the leakage content within the standard specifications. Therefore, according to this, re-search, sugarcane bagasse fibers proved to
\end{abstract}


be a viable alternative for SMA-type mixtures. Thus, the application of this material in asphalt paving and improving some essential characteristics can significantly reduce the environmental impacts generated by the inadequate disposal of these residues by sugar mills.

Keywords: Mechanical performance; Asphalt mixtures; Agricultural waste; Superpave; Sustainability.

\section{Resumo}

O bagaço de resíduos da indústria açucareira contém muitos materiais de fibra natural e a aplicação de fibras naturais nas misturas asfálticas tipo SMA (Stone Matrix Asphalt) tornou-se uma alternativa atra-ente para a construção de pavimentos flexíveis. O objetivo deste estudo é avaliar o desempenho mecâ-nico de mistura asfáltica modificada por incorporação de fibra do bagaço de cana de açúcar em $0.3 \%$ e com tamanho de $20 \mathrm{~mm}$. Para realização desta pesquisa o ligante asfáltico utilizado foi submetido a ensaios de penetração, ponto de amolecimento e viscosidade rotacional, e os agregados caracterizados por meio dos ensaios de massa específica, granulometria e absorção. A dosagem Superpave foi realiza-da para produção dos corpos de prova a serem avaliados nos ensaios de resistência à tração por compressão diametral, módulo de resiliência, estabilidade Marshall e escorrimento. A mistura asfáltica modificada apresentou melhor desempenho em todos os ensaios de resistência avaliados e o teor de escorrimento dentro das especificações em norma. Portanto, as fibras do bagaço de cana, de acordo com esta pesquisa, mostraram-se uma alternativa bastante viável para as misturas do tipo SMA. A aplicação desse material na pavimentação asfáltica além de melhorar algumas características essenciais, pode contribuir significativamente para a redução dos impactos ambientais gerados pelo descarte ina-dequado destes resíduos pelas usinas de açúcar.

Palavras-chave: Desempenho mecânico; Misturas asfálticas; Resíduo agrícola; Superpave; Sustentabilidade.

\section{Resumen}

El bagazo de desecho de la industria azucarera contiene muchos materiales de fibras naturales y la aplicación de fibras naturales en mezclas asfálticas como SMA (Stone Matrix Asphalt) se ha convertido en una alternativa atractiva para la construcción de pavimentos flexibles. El objetivo de este estudio es evaluar el comportamiento mecánico de una mezcla asfáltica modificada mediante la incorporación de $0.3 \%$ de fibra de bagazo de caña de azúcar y con un tamaño de $20 \mathrm{~mm}$. Para la realización de esta investigación, el ligante asfáltico utilizado se sometió a pruebas de penetración, punto de reblandecimiento y viscosidad rotacional, y los agregados se caracterizaron mediante pruebas específicas de masa, tamaño de partícula y absorción. La dosificación de Superpave se realizó para la producción de probetas a evaluar en los ensayos de resistencia a tracción por compresión diametral, módulo de resiliencia, estabilidad Marshall y pandeo. La mezcla de asfalto modificado mostró un mejor desempeño en todas las pruebas de resistencia evaluadas y el contenido de pandeo dentro de las especificaciones estándar. Por tanto, las fibras de bagazo de caña de azúcar, según esta investigación, demostraron ser una alternativa muy viable para las mezclas tipo SMA. La aplicación de este material en pavimentos asfálticos, además de mejorar algunas características esenciales, puede contribuir significativamente a reducir los impactos ambientales que genera la disposición inadecuada de estos residuos por los ingenios azucareros.

Palabras clave: Rendimiento mecânico; Mezclas asfálticas; Residuos agrícolas; Superpave; Sustentabilidad.

\section{Introduction}

Conventional asphalt mixes can perform well in most flexible pavement applications. However, the trend has been increased traffic, severe weather conditions, and heavier loads in recent years. Thus, pavements have raised the demand for improvements in the mechanical properties of traditional asphalt materials through modifications (Liang et al., 2015; Mohammed et al., 2020; Varuna et al., 2020; Khasawneh \& Alyaseen, 2020).

Agricultural activities produce significant residues from the harvest (Tripathi et al., 2019). Biomass acquired from plants or crops consists mainly of straw, bark, and bagasse. The high generation of agricultural waste generates serious environmental problems and issues associated with the landfill (Amin et al., 2019). It is known that fiber is a type of reinforced material, and application in composites has become an essential alternative in the preparation of materials because of its excellent properties (Klinsky et al., 2018; Badeli et al., 2018; Kim et al., 2018; Kim et al., 2018; Slebi-Acevedo et al., 2019).

The use of fibers in SMA-type asphalt mixtures (Stone Matrix Asphalt) has become a desirable alternative for constructing asphalt pavements. Gradually, natural fibers were incorporated into asphalt mixtures showing an improvement in fatigue resistance and permanent deformation (Abiola et al., 2014). Studies show the effectiveness of this material in asphalt mixtures. Caro et al. (2016) investigated the incorporation of agro-industrial residues (sugarcane bagasse, corn cobs, and rice husks) in the properties of the asphalt binder. The authors point out that the biomaterials provided an increase in the stiffness of 
the ligand.

Chen et al. (2019) developed research to evaluate the properties of the asphalt binder modified with cornstalk fibers. The results indicated that incorporating these fibers increased the performance of the binder at high temperatures and decreased its temperature sensitivity. Finally, Costa et al. (2019) investigated the effects of adding banana fibers of different lengths to hot asphalt mixes. The results showed that banana fibers could reduce the drainage of hot asphalt mixes, and the modified mixes showed resistance to permanent deformation again.

Bellatrache et al. (2020) analyzed the performance of the asphalt binder with palm fibers, which indicated an improvement in the physical-mechanical characteristics of the binder. Mohammed et al. (2020), in their study on the microstructure and mechanical properties of fiber-reinforced asphalt mixtures, verified an increase in stiffness and a gain in fatigue, tensile and damage resistance due to induced moisture. Finally, Xing et al. (2020) investigated the effects of incorporating various fibers, including lignin, on the properties of the asphalt binder. It was concluded that natural fibers such as lignin could stabilize the binder and improve the resistance to permanent deformation.

Pirmohammad and Mengharpey (2020) evaluated the influence of natural kenaf and basalt fibers on the fracture strength of hot asphalt mixtures. The results showed that both fibers provided increased fracture strength. The addition of $0.3 \%$ of fibers showed the best performance in strength. Among them, the mixture with kenaf fiber obtained the most significant strength gain. Khasawneh and Alyaseen (2020) observed in their study of asphalt mixtures modified with coconut fibers that incorporation increased Marshall stability.

$\mathrm{Li}$ et al. (2020) investigated the performance of asphalt mixtures with the incorporation of $0.2 \%$ of sugarcane bagasse fibers compared to asphalt mixtures modified by lignin fibers. The results showed that bagasse fibers have a corrugated surface and irregular lumens and contain cellulose, hemicellulose, and aromatic polymers, mainly composed of amorphous components and natural polysaccharides similar to fibers containing lignin. In addition, bagasse fibers improve fatigue resistance and permanent deformation of asphalt mixtures. However, the performance of both blends was very similar.

Thus, in order to contribute to studies on the addition of natural fibers in asphalt mixtures, this study aims to evaluate the mechanical performance of a modified SMA asphalt mixture by incorporating $0.3 \%$ of sugarcane bagasse fibers.

\section{Methodology}

This topic describes the materials and procedures performed during the experimental phase of the research, performed by the standards of the American Society for Testing and Materials (ASTM), the American Association of State Highway and Transportation Officials (AASHTO), and the National Department of Infrastructure and Transport (DNIT).

\subsection{Materials}

The asphalt binder used in this research was Petroleum Asphalt Cement with a 50/70 degree of penetration (PAC 50/70), supplied by JBR Engenharia LTDA, located in the city of Recife-PE. The study used granitic aggregates, $19 \mathrm{~mm}, 9.5$ $\mathrm{mm}$, and stone powder, all from the Rocha Cavalcante quarry in Campina Grande-PB. The lime used in the research was acquired in the local commerce of the same city.

The sugarcane bagasse fibers used came from the Feira Central located in the city of Campina Grande-PB. The fiber pieces were cut with a cutting tool to the lengths used in this work. The manual process used to obtain the fibers was only viable because the number of fibers needed for this study was small. Therefore, mechanical extraction and cutting techniques are recommended. According to Li et al. (2020), generally, the length of sugarcane bagasse fibers is less than $8 \mathrm{~mm}$, and Vale et al. (2014) point out that workability decreases when natural fibers larger than $20 \mathrm{~mm}$ are added to SMA mixtures. Therefore, 
in this study, a length of $20 \mathrm{~mm}$ was adopted for the fibers incorporated in the asphalt mixtures. Figure 1 shows the fiber from sugarcane bagasse used in this research.

Figure 1: Fibers from sugarcane bagasse.

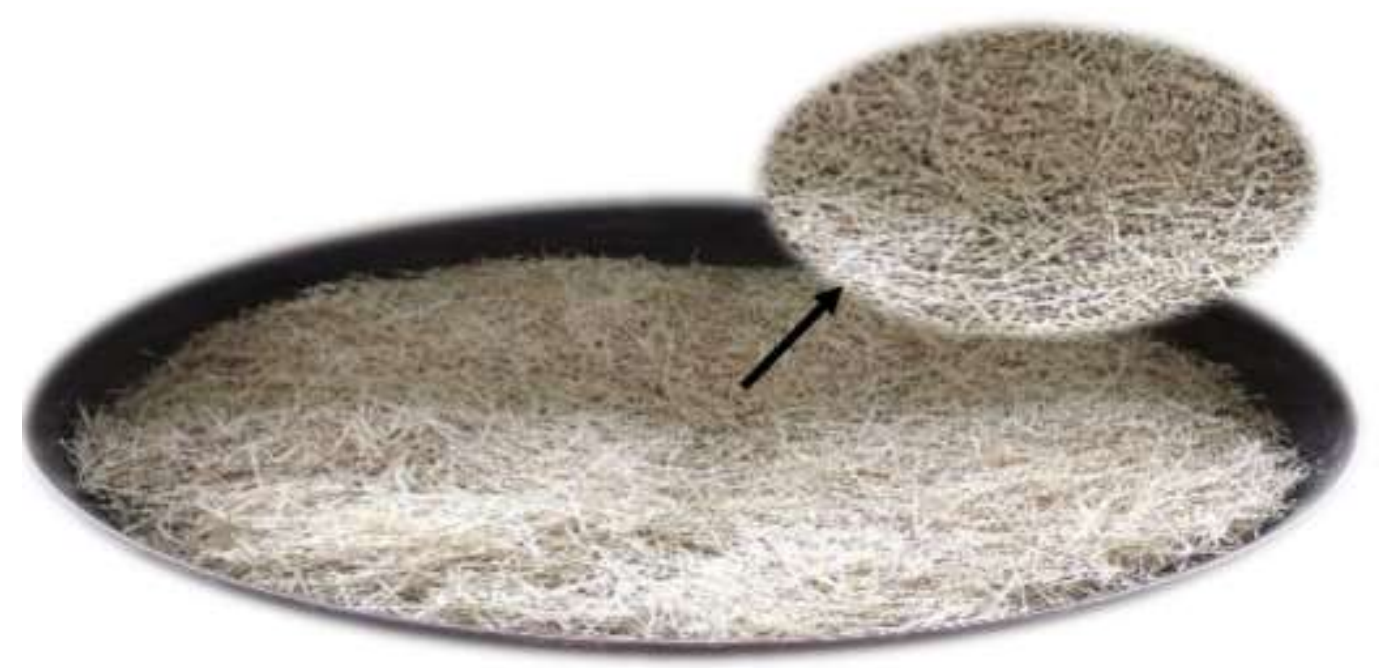

Source: Authors (2021).

Table 1 presents the physical characterization of the aggregates used in this research. In addition, the coarse and fine aggregates were also characterized according to their particle size distribution according to the ASTM C136M (2019) standard, and the series of sieves used in this test were the ones with the following openings: $25 \mathrm{~mm}, 19.1 \mathrm{~mm}, 12.7 \mathrm{~mm}, 9.5 \mathrm{~mm}, 4.8$ $\mathrm{mm}, 2 \mathrm{~mm}, 0.42 \mathrm{~mm}, 0.18 \mathrm{~mm}$ and $0.074 \mathrm{~mm}$. Figure 2 shows the particle size distribution of the aggregates.

Table 1: Physical characterization of aggregates.

\begin{tabular}{|c|c|c|c|c|}
\hline \multirow{2}{*}{ TEST } & \multirow{2}{*}{ STANDARD } & \multicolumn{3}{|c|}{ AGGREGATE } \\
\hline & & $19.0 \mathrm{~mm}$ & $9.5 \mathrm{~mm}$ & Grit \\
\hline Actual specific mass $\left(\mathrm{g} / \mathrm{cm}^{3}\right)$ & $\begin{array}{c}\text { ASTM C127 (2015) / } \\
\text { ASTM C128 (2015) }\end{array}$ & 2.77 & 2.52 & 2.3 \\
\hline Apparent specific mass $\left(\mathrm{g} / \mathrm{cm}^{3}\right)$ & $\begin{array}{c}\text { ASTM C127 (2015) / } \\
\text { ASTM C128 (2015) }\end{array}$ & 2.71 & 2.70 & 2.52 \\
\hline Absorption (\%) & $\begin{array}{l}\text { ASTM C127 (2015) / } \\
\text { ASTM C128 (2015) }\end{array}$ & 0.51 & 0.95 & 0.15 \\
\hline
\end{tabular}

Source: Authors (2021). 
Figure 2: Particle size distribution of aggregates.

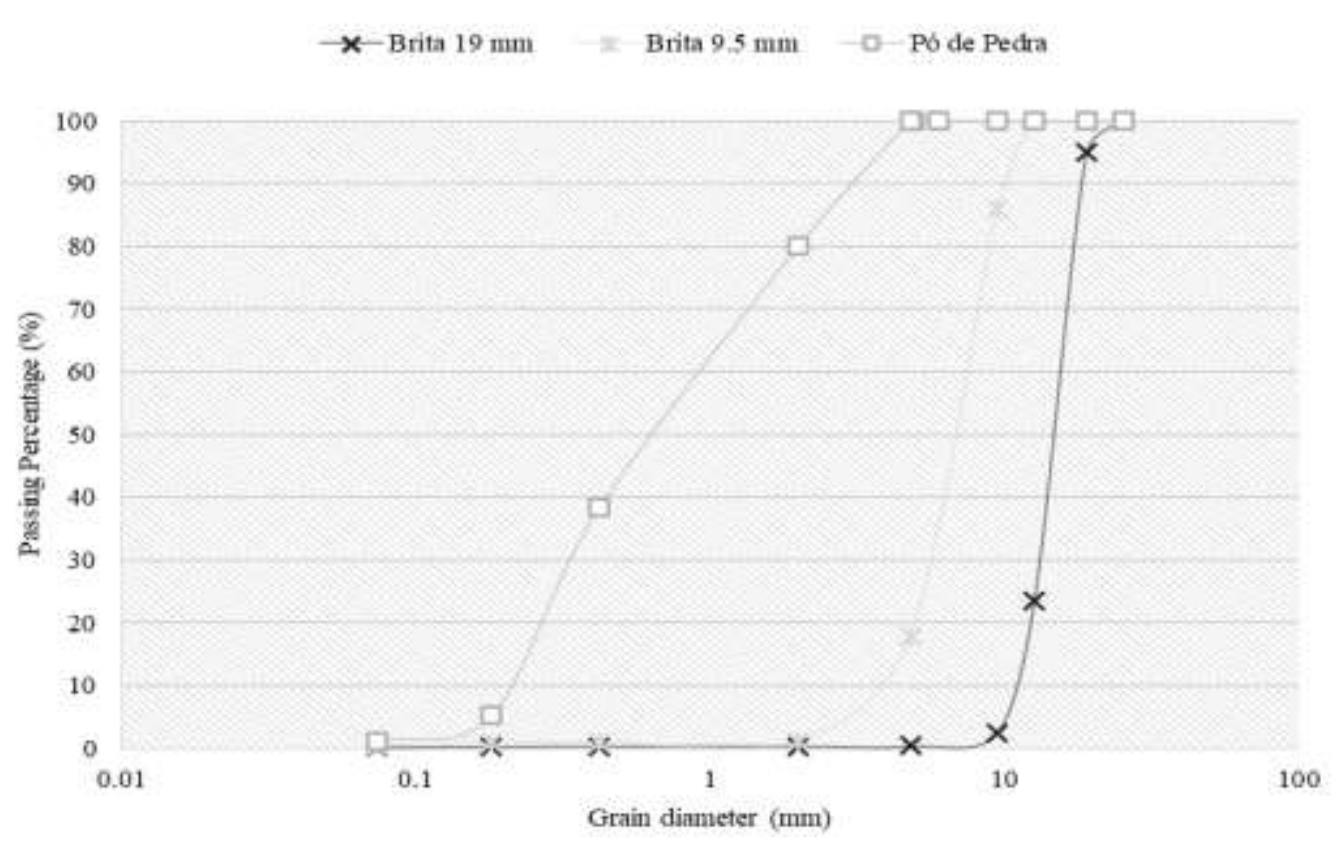

Source: Authors (2021).

According to the behavior obtained for the size distribution of lime, as shown in Figure 3, the curve showed modal behavior with an average diameter of $9.87 \mu \mathrm{m}$, with D10 of $0.47 \mu \mathrm{m}$, D50 of $4.28 \mu \mathrm{m}$ and D90 of $30.84 \mu \mathrm{m}$. Thus, for this lime, there are no particles larger than $100 \mu \mathrm{m}$. Analyzing the values obtained, it is verified that the lime has a high content of fines, presenting for the diameter of $5 \mu \mathrm{m}$ a percentage of $54.30 \%$.

Figure 3: Lime particle size distribution.

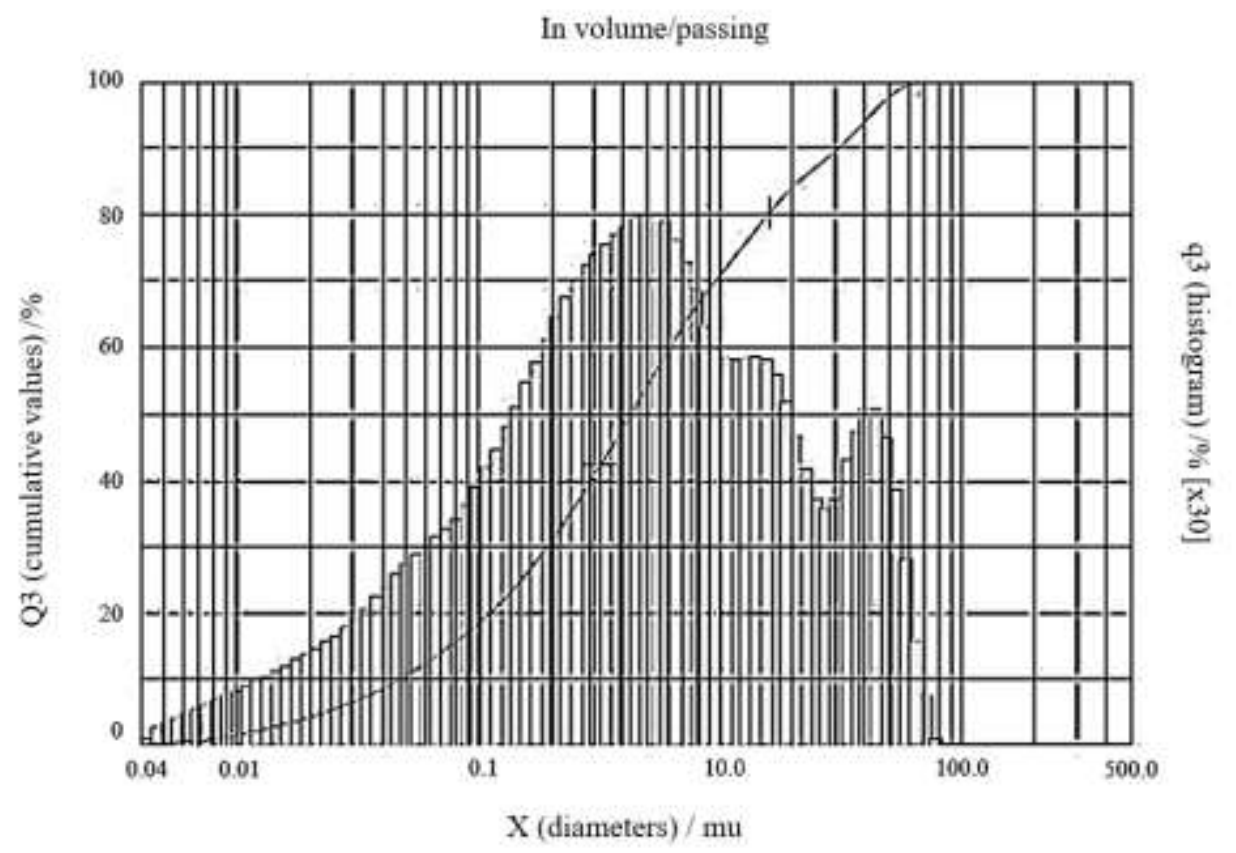

Source: Authors (2021). 
The asphalt binder was physically characterized according to ASTM standards. Table 2 presents the results of the characterizations of the ligand under study.

Table 2: Asphalt binder properties.

\begin{tabular}{c|c|c|c}
\hline TEST & LIMITS & RESULT & STANDARD \\
\hline $\begin{array}{c}0.1 \mathrm{~mm} \text { penetration } \\
\left(100 \mathrm{~g}, 5 \mathrm{~s} \text { at } 25^{\circ} \mathrm{C}\right)\end{array}$ & $50-70$ & 53.00 & ASTM D5M (2020) \\
\hline Softening Point $\left({ }^{\circ} \mathrm{C}\right)$ & $\geq 46$ & 48.00 & ASTM D36M-14 (2020) \\
\hline Rotational Viscosity $(\mathrm{cP})$ & $\geq 274$ & $432.50\left(\mathrm{a} 135^{\circ} \mathrm{C}\right)$ & \\
& $\geq 112$ & $223.50\left(\mathrm{a} 150^{\circ} \mathrm{C}\right)$ & ASTM D4402M (2015) \\
& $57-285$ & $86.5\left(\mathrm{a} 177^{\circ} \mathrm{C}\right)$ & \\
\hline
\end{tabular}

Source: Authors (2021).

The value obtained in the penetration test was 53 tenths of a millimeter, an average value after taking five penetration readings, thus being within the parameters of Resolution No. 19 of the National Petroleum Agency - ANP (2005), which establishes a range of classification for the penetration values of PAC 50/70 binders between 50 to 70 tenths of a millimeter. In order to verify the sensitivity of the binder to temperature variation, the softening point test was carried out, obtaining an average value of $48^{\circ} \mathrm{C}$ that fits with the minimum limit value established in the resolution of ANP No. 19 (2005), which is a temperature of $46^{\circ} \mathrm{C}$ in average condition. Viscosity results obtained at all temperatures fall within limits specified by ASTM D4402M (2015). Therefore, the asphalt binder used in this research satisfied the normative parameters.

According to studies carried out by Bernucci et al. (2010), the temperature of the binder when mixed with the aggregate must be such that its viscosity is between 150 and $190 \mathrm{cP}$ (Range I). The temperature of the aggregates must be $10^{\circ} \mathrm{C}$ to $15^{\circ} \mathrm{C}$ higher than the temperature of the binder. In addition, binder and aggregate temperatures must not be lower than $107^{\circ} \mathrm{C}$ or higher than $177^{\circ} \mathrm{C}$. Therefore, the compaction temperature must be such that the binder has a viscosity between 250 and $310 \mathrm{cP}$ (Range II). It is essential to highlight that the values obtained align with ANP No. 19 (2005) resolution, which stipulates minimum values of $274 \mathrm{cP}$ at $135^{\circ} \mathrm{C}, 112 \mathrm{cP}$ at $150^{\circ} \mathrm{C}$, and $28-114 \mathrm{cP}$ at $177^{\circ} \mathrm{C}$.

The temperature of the mixture (machining) expressed in the Range I obtained is $157^{\circ} \mathrm{C}$; this value is associated with a viscosity of $170 \mathrm{cP}$ commonly used in the literature, linked to a $10^{\circ} \mathrm{C}$ increase in the temperature previously obtained for heating the aggregates. On the other hand, the compaction temperature is given by Range II, in which the value of $145^{\circ} \mathrm{C}$ was obtained for mixing the aggregates to the binder. Finally, it is important to mention an aspect noted by Gama (2016) in his studies, where very low viscosities can cause slippage of the asphalt mixture when compacted by the action of compaction rollers.

\subsection{Methods}

The study is a laboratory analysis, that is, the collected and discussed results were obtained through controlled laboratory conditions (Pereira et al., 2018). The experimental program of the study was carried out in two stages: the first consists of the Superpave dosing process of the asphalt mixture, and the second stage corresponds to the analysis of the mechanical properties of the mixtures. 


\subsubsection{Superpave Dosage}

The Superpave dosage, standardized by AASHTO M 325-08 (2017), was chosen to determine the optimal content of the asphalt binder for a pre-established particle size curve. From the Fuller curve and the granulometry of the aggregates, a dosage that was within the parameters of the AASHTO M 325-08 (2017) standard was determined. Figure 4 shows the design mixture delimited by the granulometric bands of the referred standard.

Figure 4: Design mix delimited by particle size bands.

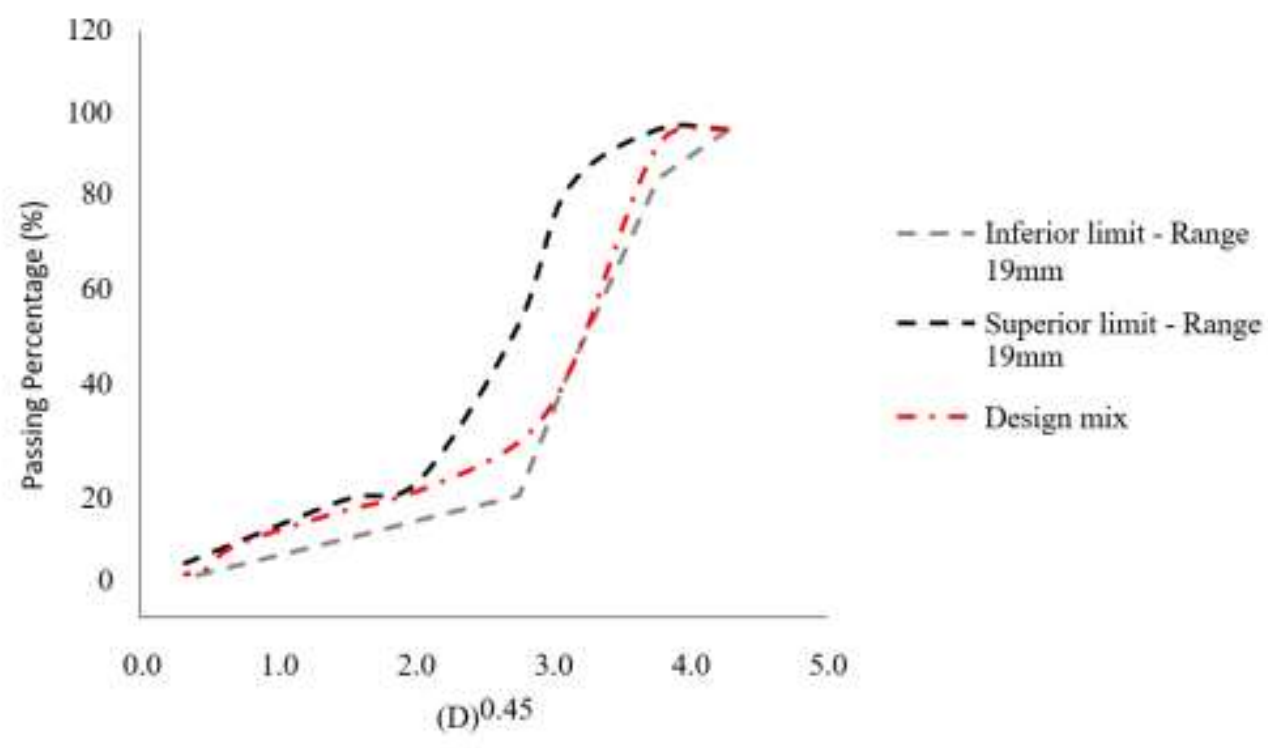

Source: Authors (2021).

Figure 4 shows the Fuller curve adopted to determine the proportion of aggregates used to find the optimum content of the binder in the mixture. It is of fundamental importance to highlight that, according to the studies carried out by Costa (2017), the initial binder content (6\%) was insufficient for the superior and intermediate granulometric compositions, making it impossible to obtain the necessary homogenization of the material. Therefore, the starting point of the research was to adjust the particle size curve to the lower limit, with a bit of inaccuracy, according to Figure 4 , as the results of the particle size analysis did not favor the approximation to the maximum of the lower limit.

The proportion of aggregates to determine the optimum content of asphalt binder was $64 \%$ for $19 \mathrm{~mm}$ gravel, $12.5 \%$ for $9.5 \mathrm{~mm}$ gravel, $15 \%$ for stone powder, and $8.5 \%$ for filler (lime). From this dosage, he determined the quantities of inputs used to determine the optimum binder content of the asphalt mixture, as shown in Table 3. 
Table 3: Quantity of materials used to determine the optimal content of PAC 50/70.

\begin{tabular}{c|c|c|c|c|c}
\hline \multicolumn{2}{|c|}{ THE AMOUNT (\%) } & Frit & $\begin{array}{c}\text { PAC } \\
50 / 70\end{array}$ \\
\hline \multirow{2}{*}{ Mix 01 } & Gravel 19 mm & Gravel 9.5 mm & 14.18 & 8.03 & 5.5 \\
\hline Mix 02 & 60.48 & 11.81 & 14.1 & 7.99 & 6 \\
\hline Mix 03 & 60.16 & 11.75 & 14.03 & 7.95 & 6.5 \\
\hline Mix 04 & 59.84 & 11.69 & 13.95 & 7.91 & 7 \\
\hline
\end{tabular}

Source: Authors (2021).

The specimens were molded to find the optimum binder content to be used in the SMA asphalt mixture. Therefore, the optimal percentage of binder is associated with the volumetry parameters of each specimen in which it is calculated: the Void Volume, Bitumen/Void Ratio, and Mineral Aggregate Voids (VAM). Therefore, the specimens were molded with the contents of $5.5,6,6.5$, and $7 \%$ for further analysis of the properties mentioned above, so all the criteria adopted to obtain the optimum binder content was through the standard AASHTO M 325 -08 (2017). As a result, the optimum content of asphalt binder established was $6.2 \%$. Table 4 presents the results obtained for the volumetric parameters, which fit within the pre-established parameters and the number of component materials of the asphalt mixtures, with and without the addition of sugarcane bagasse fibers.

Table 4: Results of the volumetric and quantitative parameters of the component materials of the asphalt mixtures.

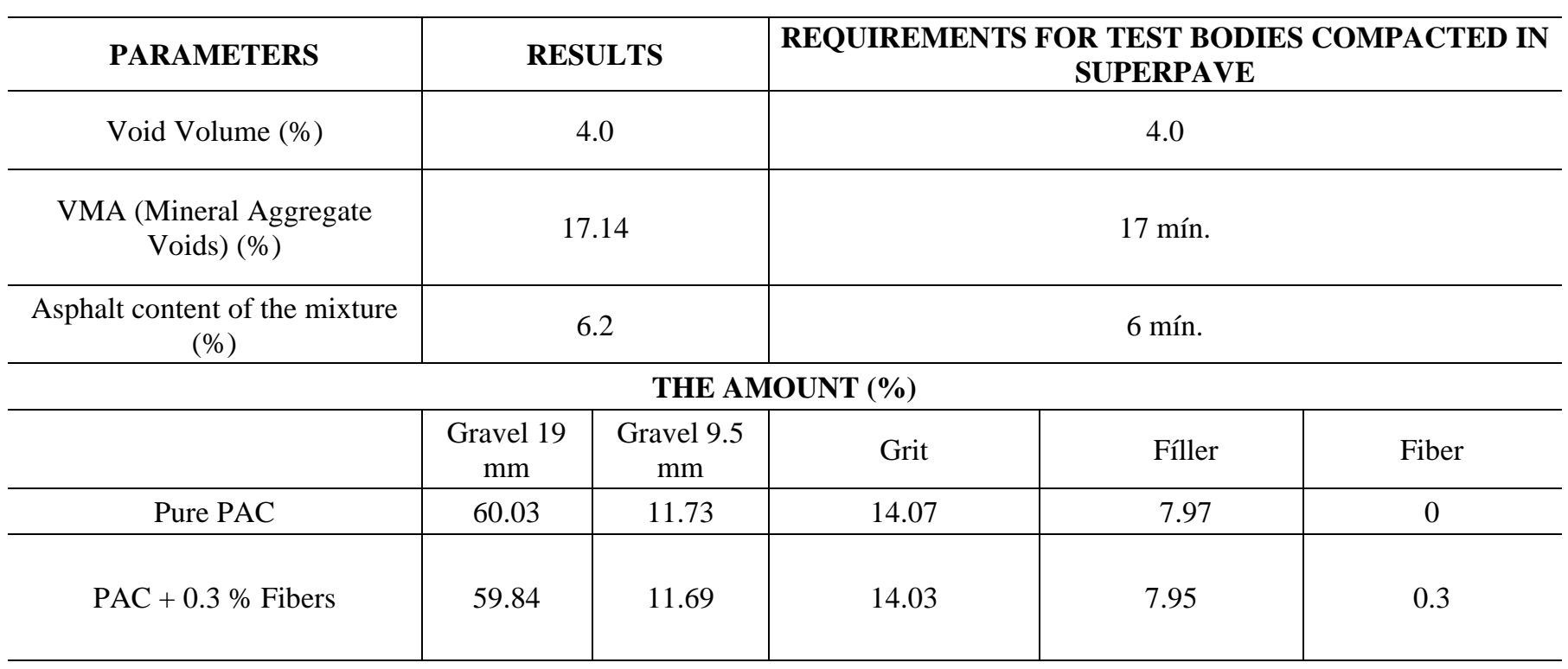

Source: Authors (2021).

The choice of the percentage of fiber incorporation from sugarcane bagasse was $0.3 \%$, determined from information extracted from previous researches with the addition of natural fibers in asphalt mixtures (Pirmohammad \& Mengharpey, 2020; Costa, 2017). Li et al. (2020) investigated the influence of incorporating sugarcane bagasse fibers in the $0.2 \%$ content, 
which justifies the use of a slightly higher content in this research to analyze the performance of SMA mixtures at $0.3 \%$ of fibers from the sugarcane bagasse.

\subsubsection{Mechanical Tests}

The Splitting tensile strength test (ST) was determined through the test that follows the DNIT-ME 136 (2018) standard specifications. Initially, three parallel diameters and four diametrically opposite heights of the specimen were measured, using a caliper to obtain the average of the corresponding values, respectively, for diameter and height. Next, the specimen was placed in an oven until reaching a temperature of $25^{\circ} \mathrm{C} \pm 0.1{ }^{\circ} \mathrm{C}$; then, the specimen was positioned on a cylindrical surface between two metal strips. When the plates were adjusted to exert a light compression capable of maintaining the specimen, the load was progressively applied with a deformation speed of $0.8 \pm 0.1 \mathrm{~mm} / \mathrm{s}$ until rupture occurred by separating the two halves of the specimen. Finally, test according to the vertical diametral plane, acquiring the breaking load that determines the maximum stress supported by the asphalt mixture before breaking.

The Resilient Modulus (RM) test was performed as recommended by the DNIT-ME 135 (2018) standard, where the IPC UTM-25 hydraulic press was used in which cylindrical specimens of approximately $10 \mathrm{~cm}$ in diameter per $6.5 \mathrm{~cm}$ in height were placed in a mold and subsequently a compressive load in a pulsating waveform was applied. A load equal to $10 \%$ of the tensile strength value was applied, at a frequency of 60 cycles per minute $(1 \mathrm{~Hz})$, with an application time of $0.1 \mathrm{~s}$ and 0.9s of rest or unloading. The DNIT-ME 043 (1995) standard establishes the guidelines for carrying out the Marshall Stability test, which measures the maximum strength in $\mathrm{N}$ (Kgf) (diametric compression) of a tested specimen. The importance of this test lies in the fact that the mixture must have shear strength compatible with the efforts that will be applied to it. The procedure began with the immersion of the specimens in a water bath for 30 to 40 minutes; then, each specimen was placed in a compression mold at a temperature of $60^{\circ} \mathrm{C}$. The compression mold containing the specimen is positioned in the press according to the generatrix, and the creep meters are placed and adjusted in the test position. The press is operated so that its piston rises at a speed of $5 \mathrm{~cm}$ per minute until the breakage of the specimen, which is observed in the deflectometer by indicating a maximum. The splitting tensile strength test, resilient modulus, and Marshall stability followed the procedures adopted by Carvalho et al. (2021).

The Draindown Sensitivity of asphalt mixtures aims to evaluate the amount of material runoff (drip) from a noncompacted hot sample when subjected to high temperatures, comparable to those used in production, storage, transport, and spreading. Thus, this experiment follows the recommendations established in the standard AASHTO T 305-14 (2018), which advocates, among other factors, a maximum sag of $0.3 \%$ of the total weight tested. Therefore, the experiment was carried out according to the recommendations of the standard, which boils down to placing the mixture (1200 g $\pm 5 \mathrm{~g})$ in a wire basket positioned on a plate in an oven for $60 \pm 5$ minutes and then obtaining the adhered binder mass to the plate.

\section{Results and Discussion}

This section presents and discusses the results obtained in the experimental phase of asphalt mixtures modified with sugarcane bagasse fibers. All mechanical test results were obtained from the average of three samples for each mixing group.

\subsection{Splitting tensile strength test (ST)}

The tensile strength test aimed to evaluate the maximum tensile strength of specimens with and without fibers. Therefore, it is of fundamental importance to highlight that the length of the fibers has considerable relevance for a better test result in terms of rupture tension, so the size adopted for analysis was $20 \mathrm{~mm}$, as mentioned above. Figure 5 presents the tensile strength results for the evaluated mixtures. 
Figure 5: Splitting tensile strength test results of SMA blends.

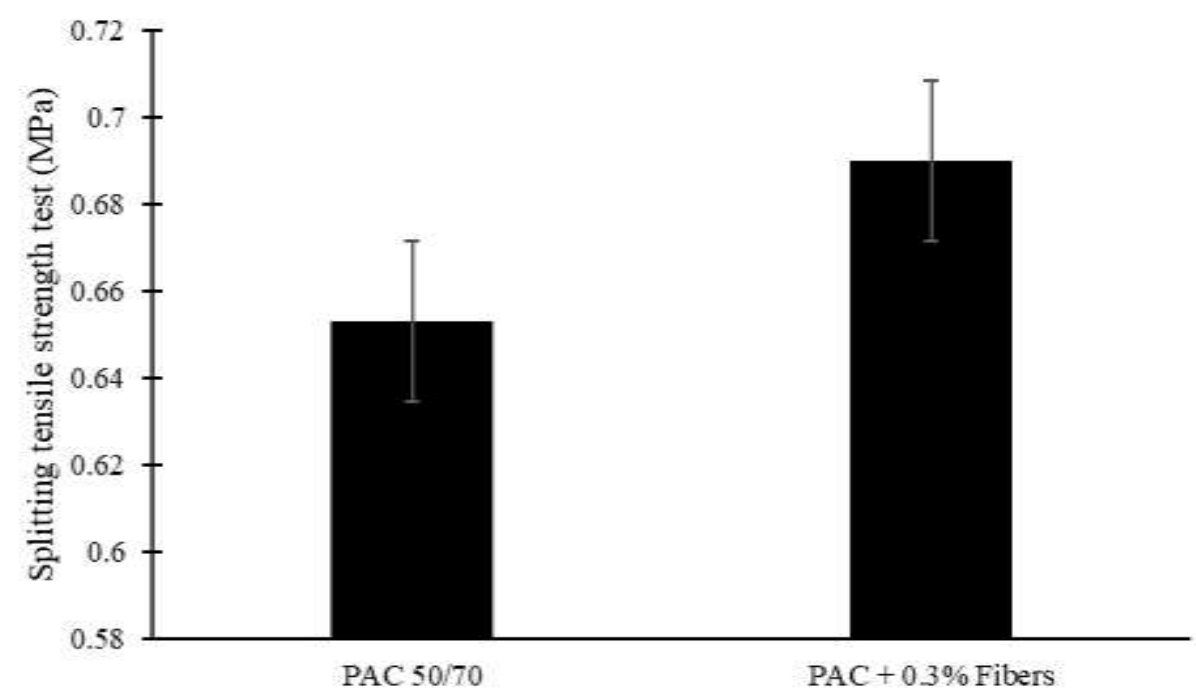

Source: Authors (2021).

Based on the results obtained in Figure 5, it can be seen that the incorporation of fibers from sugarcane bagasse to the SMA mixture caused a gain in tensile strength. It is verified that there was an increase of $5.67 \%$ in the tensile strength when adding the fibers. This result corroborates previous research carried out by Valença (2012) in which they evaluated SMA mixtures modified with curauá fibers, Vale et al. (2014) with coconut fibers, Costa et al. (2019) with banana fibers, and Mohammed et al. (2020) with cellulose fibers. Li et al. (2020) did not analyze the tensile strength of mixtures with sugarcane bagasse fibers.

According to DNIT-ES 031 (2006), the minimum value for tensile strength is $0.65 \mathrm{MPa}$ for bearing layers. However, according to Figure 5, the results obtained were higher than the minimum required by DNIT.

\subsection{Resilient Modulus (RM)}

The Resilient Modulus test investigates the relationship between the horizontal stress resulting from the cyclic load and the corresponding horizontal deformation obtained from the recoverable displacement (resilient) of the specimen under analysis. Therefore, the load used in the evaluation of this experiment must be between $5 \%$ to $25 \%$ of the tensile strength according to the specifications of DNIT-ME 135 (2018), being used in the test $10 \%$ of the test mentioned above value. Figure 6 shows the results obtained in the resilient modulus test for the SMA asphalt mixtures, tested at a temperature of $25^{\circ} \mathrm{C}$. 
Figure 6: Results of the resilient modulus of SMA mixtures.

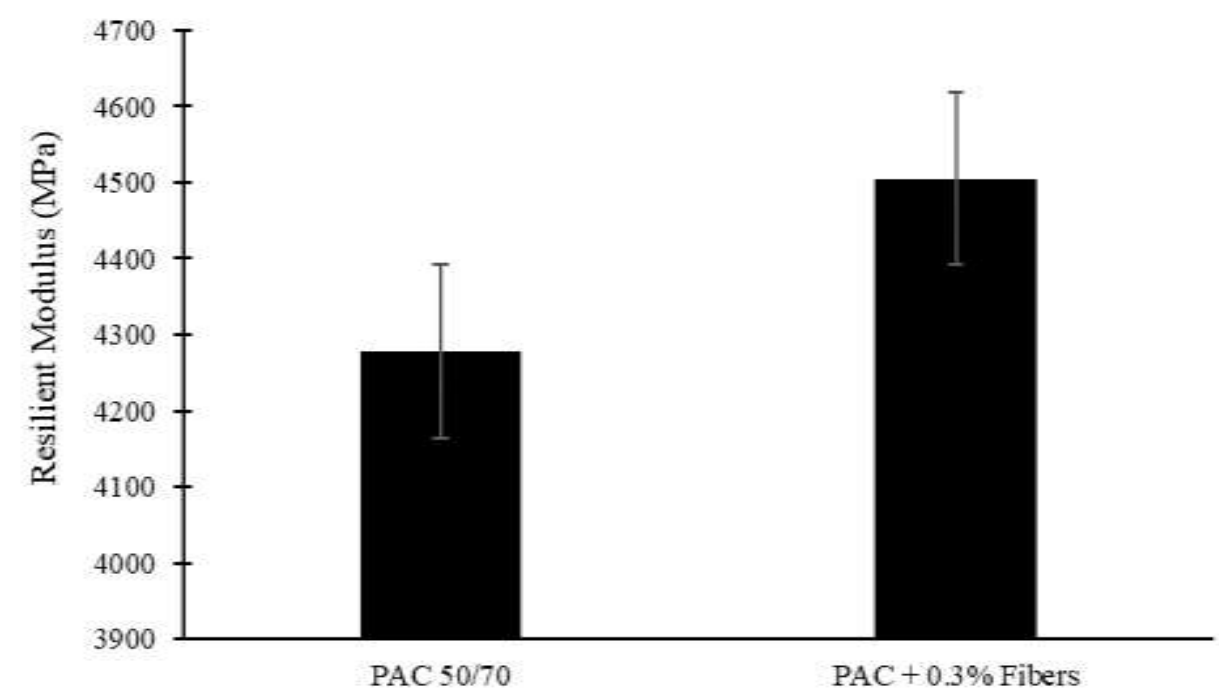

Source: Authors (2021).

Incorporating sugarcane bagasse fibers into the hot asphalt mixture increased the resilient modulus value, indicating the modified asphalt mixture is more resilient than the conventional one. The gain of the modified mixture compared to the conventional one was 5.32\%. According to Bernucci et al. (2010), the modulus of resilient values for dense asphalt mixtures should lie within a range of 2000 to $8000 \mathrm{MPa}$. In this research, the modulus of resilient values obtained was within the usual Range mentioned above.

According to a study carried out by Leal (2013), with the addition of sugarcane bagasse fibers with a size of less than $1.2 \mathrm{~mm}$ in asphalt mixtures, an increase in modulus for mixtures with cellulose fibers was observed. Thus, when analyzing the results obtained in this research about the study mentioned above, it is verified that there was a significant improvement when adding $0.3 \%$ of fibers in the size of $20 \mathrm{~mm}$. On the other hand, Costa et al. (2019) pointed out a decrease in the modulus of resilient of SMA mixtures by incorporating banana fibers in sizes from $5 \mathrm{~mm}$ to $20 \mathrm{~mm}$. The authors justify that the SMA mixture studied in their research contained a high percentage of asphalt binder, and the reductions in binder viscosity caused by the increase in the test temperature may have led to a destabilization of the mixture. However, the optimum binder content in the present study was equal to that of the research mentioned above, $6.2 \%$. Therefore, the behavior of reducing the modulus of resilient in the mixtures by Costa et al. (2019) may be due to the composition of the fiber itself, which is different from that used in this study.

\subsection{Resilient Modulus/ Splitting tensile strength test Ratio (RM/ST)}

Based on the results obtained for the tensile strength and resilient modulus tests, it is possible to have the relationship between these two parameters, called the RM/ST ratio, allowing to evaluate the behavior of the asphalt mixtures concerning cracking, indicating that the lower the RM/ST value, the greater the tendency for improvement in the mechanical behavior of the mixture, since it combines flexibility with good tensile strength. Thus, a reduction in the RM/ST ratio value can even lead to the use of smaller thicknesses of the coating layer for the same fatigue life. Figure 7 shows this relationship for the analyzed mixtures. 
Figure 7: RM/ST ratio of SMA asphalt mixtures.

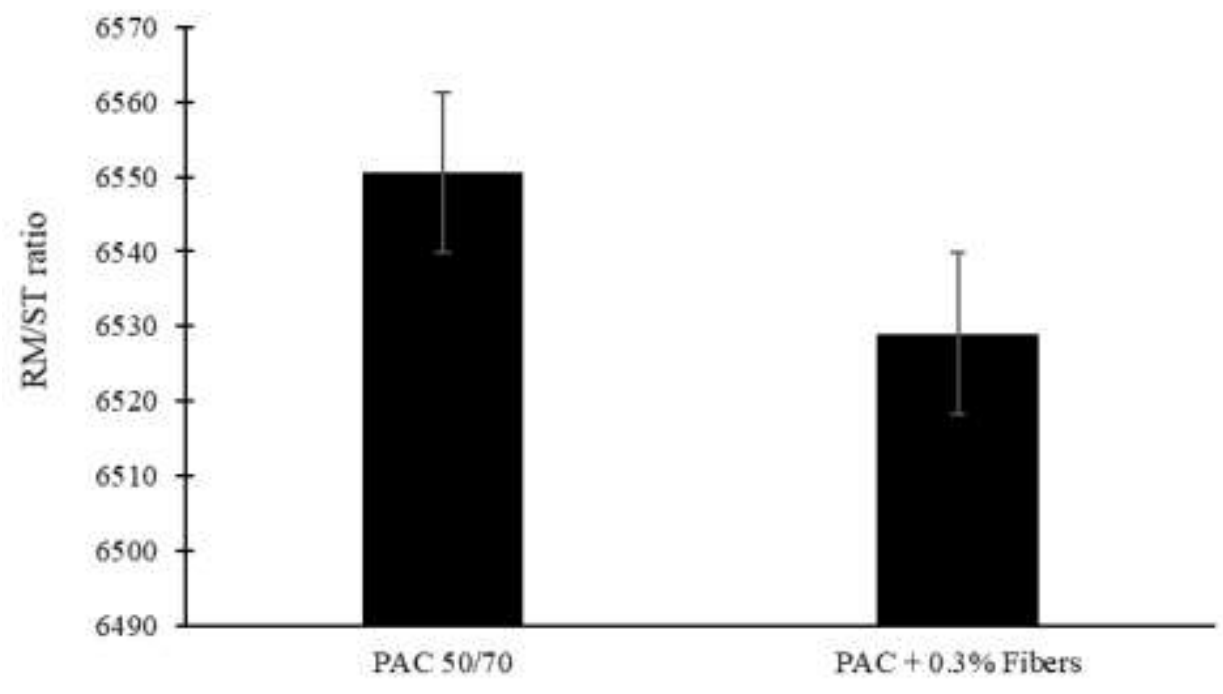

Source: Authors (2021).

The relationship between these two parameters, resilient modulus, and tensile strength, has been used as an indicator of the fatigue life of asphalt mixtures, as it analyzes the relationship between stiffness and strength (Tebaldi, 2016). Mixtures with high modulus of resilient values require high tensile strength values due to the concentration of stresses present in their interior (Boeira, 2014). The results demonstrate that the RM/ST ratio decreased with the incorporation of sugarcane bagasse fibers concerning the conventional mixture, being in the order of $0.33 \%$, which is beneficial for the performance of the asphalt mixture. Therefore, the modified asphalt mixture with bagasse fiber is less susceptible to cracking.

\subsection{Marshall Stability}

The results obtained for the Marshall stability test are shown in Figure 8. According to the specifications of the AASHTO M 325-08 standard (2017), the minimum value established is $620 \mathrm{kgf}$, verified in the SMA asphalt mixtures analyzed in this search.

Figure 8: Results of the Marshall stability test of SMA mixtures.

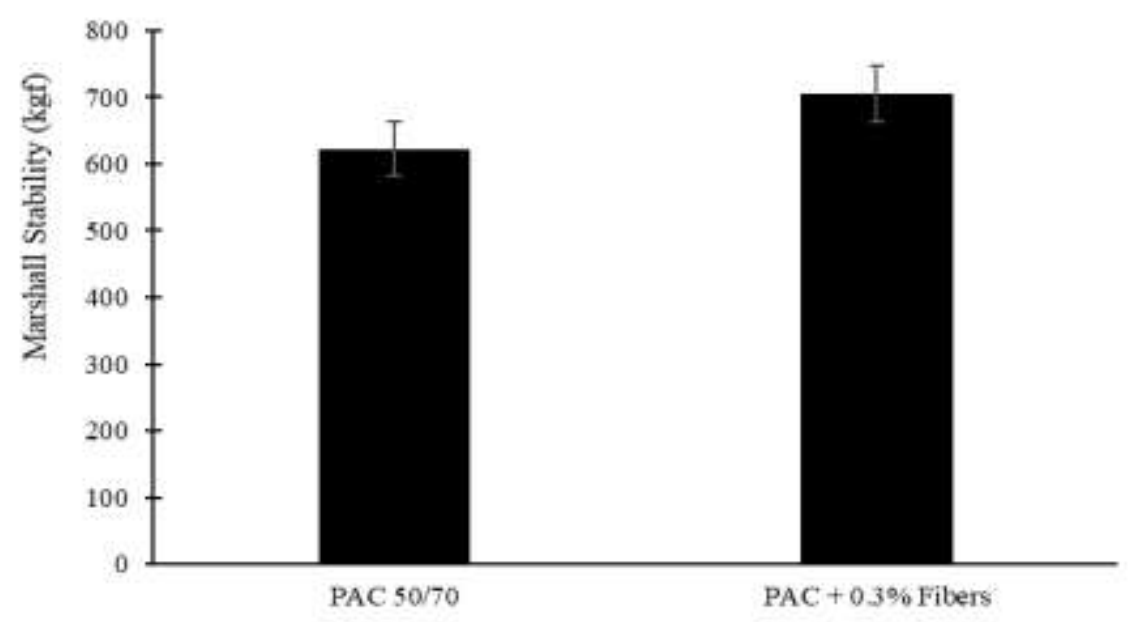

Source: Authors (2021). 
Based on the results presented in Figure 8, an increase in the Marshall stability value of $13.25 \%$ can be seen in the mixture with $0.3 \%$ of fibers about the conventional asphalt mixture. Therefore, although the DNIT-ES 031 (2006) standard establishes that the Marshall minimum stability values for the coating layer are $500 \mathrm{kgf}$, as shown in Figure 8, it modifies both the reference mixture and the asphalt mixture stability results Marshall were superior to those required by the standard.

Li et al. (2020) observed a 5.1\% increase in Marshall stability of asphalt mixes after adding $0.2 \%$ sugarcane bagasse fibers compared to the conventional mix and a $9.6 \%$ increase compared to the asphalt mix with the addition of sugarcane fibers. Lignin. Therefore, it is concluded that adding a higher fiber content of sugarcane bagasse provided a more significant gain in Marshall stability values.

\subsection{Draindown Sensitivity}

In the sag test, the behavior of the mixture with fibers $(0.3 \%)$ not compacted at temperatures of $150^{\circ} \mathrm{C}$ and $165^{\circ} \mathrm{C}$ were analyzed, which were adopted to verify the amount of binder drained from the tested samples, aiming at the existing compatibility with the production, storage, transport and spreading of asphalt mixtures. The test with the conventional asphalt mixture was not carried out because it has already been evaluated in other works in the literature and verified, for the most part, that it does not meet the maximum limit recommended by the AASHTO T 305-14 standard (2018). Figure 9 shows the runoff contents for the mixture with the addition of sugarcane bagasse fibers.

Figure 9: Draindown for fiber-modified SMA asphalt mixture.

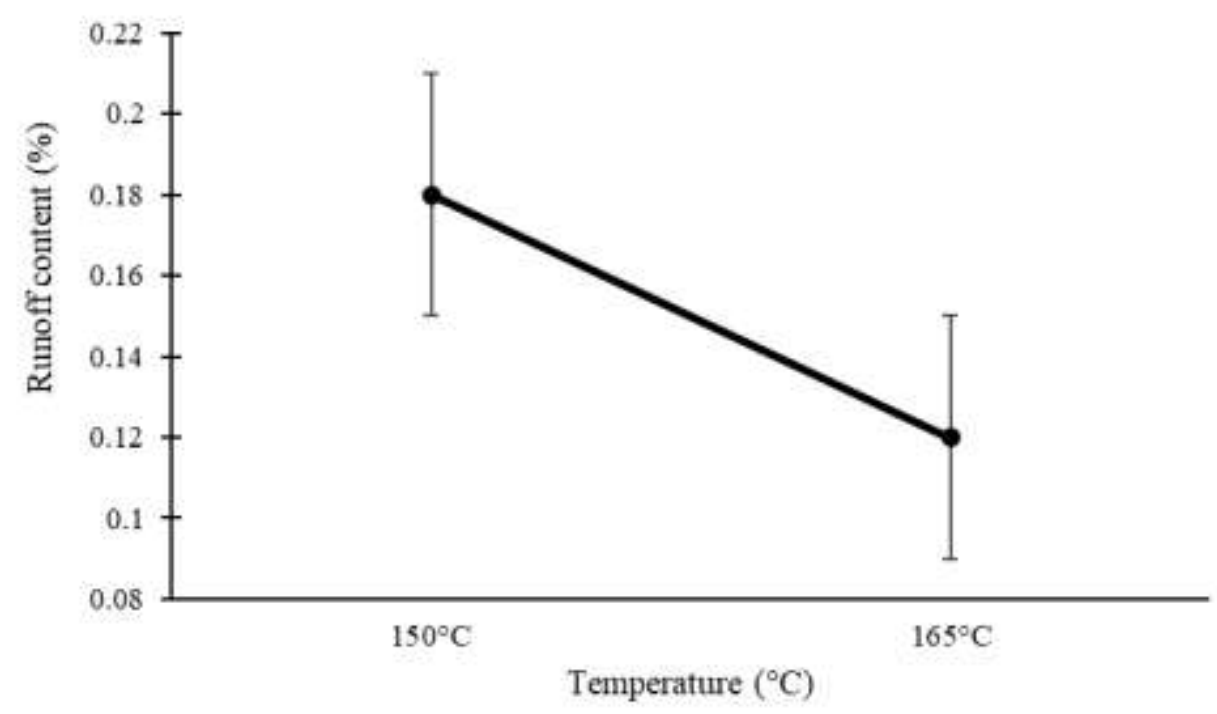

Source: Authors (2021).

According to the values obtained in the graph in Figure 9, it can be concluded that the levels of runoff at both temperatures were well below the maximum recommended by the AASHTO T 305-14 (2018) standard, which is 0.3\%. Costa et al. (2019) also verified the runoff of asphalt mixtures produced with PAC 50/70 and modified with banana fibers in the content of $0.3 \%$ at the same temperatures presented here. The authors point out the results of $0.05 \%$ for a temperature of $150{ }^{\circ} \mathrm{C}$ and $0.23 \%$ for a temperature of $165^{\circ} \mathrm{C}$.

Thus, it can be inferred that incorporating fibers from sugarcane bagasse is more effective when referring to the sag parameter. For the same incorporation content and at the same temperatures evaluated, these fibers had even lower values than banana fibers. 


\section{Conclusion}

This research evaluated the effects of incorporating sugarcane bagasse fibers in the length of $20 \mathrm{~mm}$ and the content of $0.3 \%$. Given the results obtained in the discussed tests, it could be verified that the SMA asphalt mixture using sugarcane bagasse fibers presented promising results in strength and stiffness evaluations, which matches this type of mixture.

The modified mixture showed strength gain in all tests carried out, and it is essential to highlight that the sag test showed that the mixture fits within the parameters of the analyzed standard, being essential to avoid the appearance of pathologies after the application of the mixture.

According to this study, Sugarcane bagasse fibers proved to be a very viable alternative for SMA-type mixtures. Thus, the application of this material in paving and improving some essential characteristics can significantly reduce the environmental impacts generated by the inadequate disposal of these residues by sugar mills.

For a better approach to the content treated in this research, it is suggested to study the interference of the addition of sugarcane fiber at different contents than those used in this study on the mechanical properties of asphalt mixtures, as well as to analyze the mechanical behavior of the SMA mixture with fibers of sugarcane bagasse through additional fatigue strength and dynamic modulus tests.

\section{Acknowledgments}

To the Federal University of Campina Grande (UFCG), for providing the Pavement Engineering Laboratory (LEP), in which the experimental procedures of this work were carried out.

\section{References}

Abiola, O. S., Kupolati, W. K., Sadiku, E. R., \& Ndambuki, J. M. (2014). Utilisation of natural fibre as modifier in bituminous mixes: A review. Construction and Building Materials, 54, 305-312. https://doi.org/10.1016/j.conbuildmat.2013.12.037

Agência Nacional de Petróleo. (2005). Resolução ANP N 19 , de 11 de julho de 2005.

American Association of State Highway and Transportation (2017). AASHTO M 325-08: Standard Specification for Stone Matrix Asphalt (SMA). Washington, DC.

American Association of State Highway and Transportation (2018). AASHTO T305-14: Standard Method of Test for Determination of Draindown Characteristics in Uncompacted Asphalt Mixtures. Washington, DC.

American Society for Testing and Materials (2015). ASTM C127: Standard Test Method for Relative Density (Specific Gravity) and Absorption of Coarse Aggregate. West Conshohocken.

American Society for Testing and Materials (2015). ASTM C128: Standard Test Method for Relative Density (Specific Gravity) and Absorption of Fine Aggregate. West Conshohocken.

American Society for Testing and Materials (2015). ASTM D4402M: Standard Test Method for Viscosity Determination of Asphalt at Elevated Temperatures Using a Rotational Viscometer. West Conshohocken.

American Society for Testing and Materials (2019). ASTM C136M: Standard Test Method for Sieve Analysis of Fine and Coarse Aggregates. West Conshohocken.

American Society for Testing and Materials (2020). ASTM D36M-14: Standard Test Method for Softening Point of Bitumen (Ring-and-Ball Apparatus). West Conshohocken.

American Society for Testing and Materials (2020). ASTM D5M: Standard Test Method for Penetration of Bituminous Materials. West Conshohocken.

Amin, M. N., Murtaza, T., Shahzada, K., Khan, K., \& Adil, M. (2019). Pozzolanic Potential and Mechanical Performance of Wheat Straw Ash Incorporated Sustainable Concrete. Sustainability, 11 (2). https://doi.org/10.3390/su11020519

Badeli, S., Carter, A., Doré, G., \& Saliani, S. (2018). Evaluation of the durability and the performance of an asphalt mix involving Aramid Pulp Fiber (APF): Complex modulus before and after freeze-thaw cycles, fatigue, and TSRST tests. Construction and Building Materials, 20, 60-71. https://doi.org/10.1016/j.conbuildmat.2018.04.103

Bellatrache, Y, Ziyani, L, Dony, A, Taki, M, \& Haddadi, S (2020). Effects of the addition of date palm fibers on the physical, rheological and thermal properties of bitumen. Construction and Building Materials, 239, 117808. https://doi.org/10.1016/j.conbuildmat.2019.117808 
Bernucci, L. L. B., Motta, L. M. G., Ceratti, J. A. P., \& Soares, J. B. (2010). Pavimentação Asfáltica: Formação básica para engenheiros. Petrobras/Abeda, Rio de Janeiro.

Boeira, F. D. (2014). Estudo do desempenho de concretos asfálticos com diferentes tipos de agregados e cales. Dissertação de M.Sc, Universidade Federal de Santa Maria, Santa Maria, Brasil.

Caro, S, Vega, N, Husserl, J, \& Alvarez, A. E (2016). Studying the impact of biomodifiers produced from agroindustrial wastes on asphalt binders. Construction and Building Materials, 126, 369-380. https://doi.org/10.1016/j.conbuildmat.2016.09.043

Carvalho, F. S. S., Lucena, A. E. F. L., Neto, O. M. M., Porto, T. R., \& Porto, T. M. R. (2021). Análise dos parâmetros mecânicos das misturas asfálticas com adição de óxidos metálicos. Revista Matéria, 26 (3), 2021.

Chen, Z, Yi, J, Chen, Z, \& Feng, D (2019). Properties of asphalt binder modified by corn stalk fiber. Construction and Building Materials, 212, 225-235. https://doi.org/10.1016/j.conbuildmat.2019.03.329

Costa, L. F (2017). Análise do uso das fibras do pseudocaule da bananeira em misturas asfálticas SMA". Dissertação de M.Sc., Universidade Federal de Campina Grande, Campina Grande, Brasil, 2017.

Costa, L. F, Lucena, L. C. F. L., Lucena, A. E. F. L., \& Barros, A. G. (2019). Use of Banana Fibers in SMA Mixtures. Journal of Materials in Civil Engineering, 32 (1). https://doi.org/10.1061/(ASCE)MT.1943-5533.0002994

Departamento Nacional de Infraestrutura e Transportes (1995). DNIT 043-ME: Misturas betuminosas à quente - ensaio Marshall. Rio de Janeiro.

Departamento Nacional de Infraestrutura e Transportes (2006). DNIT 031-ES: Pavimentos flexíveis - Concreto asfáltico - Especificação de serviço. Rio de Janeiro.

Departamento Nacional de Infraestrutura e Transportes (2018). DNIT 136-ME: Pavimentação asfáltica - Misturas asfálticas - Determinação da resistência à tração por compressão diametral - Método de ensaio. Rio de Janeiro.

Departamento Nacional de Infraestrutura e Transportes (2018). DNIT 135-ME: Pavimentação asfáltica - Misturas asfálticas Determinação do módulo de resiliência - Método de ensaio. Rio de Janeiro.

Gama, D A. (2016). Efeito da adição de polímeros reativo, não-reativo e ácido polifosfórico e suas combinações nas propriedades de ligantes asfálticos. Tese de D.Sc., Universidade Federal de Campina Grande, Campina Grande, Brasil.

Khasawneh, M. A., \& Alyaseen, S. K. (2020). Analytic methods to evaluate bituminous mixtures enhanced with coir/coconut fiber for highway materials. Materials Today: Proceedings, 33 (4), 1752-1757. https://doi.org/10.1016/j.matpr.2020.04.870

Kim, M, Kim, S, Yoo, D, \& Shin, H (2018). Enhancing mechanical properties of asphalt concrete using synthetic fibers. Construction and Building Materials, 178, 233-243. https://doi.org/10.1016/j.conbuildmat.2018.05.070

Klinsky, L. M. G., Kaloush, K. E., Faria, V. C., \& Bardini, V. S. S. (2018). Performance characteristics of fiber modified hot mix asphalt. Construction and Building Materials, 176, 747-752. https://doi.org/10.1016/j.conbuildmat.2018.04.221

Leal, C. L. D. (2013). Aproveitamento do bagaço de cana de açúcar em misturas asfálticas. Tese de D.Sc., Universidade Federal Fluminense, Niterói, Brasil.

Li, Z., Zhang, X., Fa, C., Zhang, Y., Xiong, J., \& Chen, H. (2020). Investigation on characteristics and properties of bagasse fibers: Performances of asphalt mixtures with bagasse fibers. Construction and Building Materials, 248, 118648. https://doi.org/10.1016/j.conbuildmat.2020.118648

Liang, M, Liang, P; Fan, W, Qian, C, Xin, X, Shi, J, \& Nan, G (2015). Thermo-rheological behavior and compatibility of modified asphalt with various styrene-butadiene structures in SBS copolymers. Materials \& Design, 88, 177-185. https://doi.org/10.1016/j.matdes.2015.09.002

Mohammed, M., Parry, T., Thom, N., \& Grenfell, J. (2020). Microstructure and mechanical properties of fibre reinforced asphalt mixtures. Construction and Building Materials, 240, 117932. https://doi.org/10.1016/j.conbuildmat.2019.117932

Pereira, A. S., Shitsuka, D. M., Parreira, F. J., \& Shitsuka, R. (2018). Metodologia da pesquisa científica. UFSM.

Pirmohammad, S, Mengharpey, M. H. (2020). Influence of natural fibers on fracture strength of WMA (warm mix asphalt) concretes using a new fracture test specimen. Construction and Building Materials, 251, 118927. https://doi.org/10.1016/j.conbuildmat.2020.118927

Slebi-Acevedo, C. J., Lastra-González, P., Pascual-Muñoz, P., \& Castro-Fresno, D. (2019). Mechanical performance of fibers in hot mix asphalt: A review. Construction and Building Materials, 200, 756-769. https://doi.org/10.1016/j.conbuildmat.2018.12.171

Tebaldi, P. D (2016). Verificação da dosagem e do comportamento mecânico do concreto asfáltico: estudo de caso. Trabalho de Conclusão de Curso, Universidade Federal de Santa Maria, Santa Maria, Brasil.

Tripathi, N, Hills, C. D., Singh, R. S.., \& Atkinson, C. J (2019). Biomass waste utilisation in low-carbon products: harnessing a major potential resource. Climate and Atmospheric Science, 2 (35). https://doi.org/10.1038/s41612-019-0093-5

Vale, A. C., Casagrande, M. D. T., \& Soares, J. S. (2014). Behavior of Natural Fiber in Stone Matrix Asphalt Mixtures Using Two Design Methods. Journal of Materials in Civil Engineering, 26 (3). https://doi.org/10.1061/(ASCE)MT.1943-5533.0000815

Valença, P. M. A. (2012). Desempenho mecânico de misturas asfálticas do tipo stone matrix asphalt com uso de fibras amazônicas e agregados de resíduos de construção e demolição. Dissertação de M.SC., Universidade Federal do Amazonas, Manaus, Brasil. 
Research, Society and Development, v. 10, n. 13, e80101320878, 2021

(CC BY 4.0) | ISSN 2525-3409 | DOI: http://dx.doi.org/10.33448/rsd-v10i13.20878

Varuna, M, Sunil, S, Anjneyappa, \& Amarnath, M. S. (2020). Studies on warm stone asphalt mixes using natural and synthetic fibres. Materials Today: Proceedings, 9. https://doi.org/10.1016/j.matpr.2020.10.497

Xing, X, Chen, S, Li, Y, Pei, J, Zhang, J, Wen, Y, Li, R, \& Cui, S (2020). Effect of different fibers on the properties of asphalt mastics. Construction and Building Materials, 262, 120005. https://doi.org/10.1016/j.conbuildmat.2020.120005 